\title{
Conflict management strategies used by Portuguese nurse managers
}

\author{
Estratégias de gestão de conflitos utilizadas por enfermeiros gestores portugueses \\ Estrategias de gestión de conflictos utilizadas por enfermeros gestores portugueses
}

\author{
Maria Manuela Martins' \\ ORCID: 0000-0003-1527-9940 \\ Leticia de Lima Trindade" \\ ORCID: 0000-0002-7119-0230 \\ Lara Vandresen"' \\ ORCID: 0000-0002-1389-7932 \\ Simone Coelho Amestoy'v \\ ORCID: 0000-0001-8310-2157 \\ Ana Paula Prata' \\ ORCID: 0000-0001-7552-9716 \\ Carlos Vilela' \\ ORCID: 0000-0002-7072-0359
}

'Escola Superior de Enfermagem do Porto. Porto, Portugal. "Universidade do Estado de Santa Catarina. Florianópolis, Santa Catarina. Brazil.

'"Universidade Federal de Santa Catarina. Florianópolis, Santa Catarina. Brazil.

"Universidade Federal de Pelotas. Pelotas, Rio Grande do Sul. Brazil.

How to cite this article: Martins MM, Trindade LL, Vandresen L, Amestoy SC, Prata AP, Vilela C. Conflict management strategies used by Portuguese nurse managers.

Rev Bras Enferm. 2020;73(Suppl 6):e20190336. doi: http://dx.doi.org/10.1590/0034-7167-2019-0336

Corresponding author:

Leticia de Lima Trindade E-mail: letrindade@hotmail.com

EDITOR IN CHIEF: Antonio José de Almeida Filho ASSOCIATE EDITOR: Fátima Helena Espírito Santo

Submission: 12-02-2019

Approval: 06-09-2020

\section{ABSTRACT}

Objectives: to analyze the perception and conflict management strategies used by nurses in the management of people in Portuguese health services. Methods: descriptive, correlational study, carried out in Portuguese health services, with an intentional non-probabilistic sample, totaling 95 nurse managers. A questionnaire and Conflict Management Scale were used, analyzing the variables of managerial activities and conflict management, with the aid of software. Results: it was identified that $60 \%$ of the managers, report having to mediate conflicts daily, and the majority report adopting dialogue in conduct. However, through the Kruskal-Wallis test, it was shown that enforcement strategies in conflict management prevail $(p=0.008)$, with collaborative ones being more restricted to monthly intervals ( $p=$ 0.049). Conclusions: managers perceive the importance of collaboration in the mediation of conflicts, however, in their daily lives; they tend to maintain imposing behaviors, signaling for a little transformational leadership style.

Descriptors: Nursing; Health Management; Health Manager; Health Services Administration; Leadership.

\section{RESUMO}

Objetivos: analisar a percepção e estratégias de gerenciamento de conflitos utilizadas por enfermeiros na gestão de pessoas em serviços de saúde portugueses. Métodos: estudo descritivo, correlacional, realizado em serviços de saúde portugueses, com amostra não probabilística intencional, totalizando 95 enfermeiros gestores. Utilizou-se um questionário e Escala de Gestão de Conflitos, sendo analisadas as variáveis de atividades gerenciais e de gestão de conflitos, com auxílio de software. Resultados: identificou-se que $60 \%$ dos gestores referem ter que mediar conflitos diariamente, e a maioria relata adotar o diálogo na conduta. Entretanto, mediante teste Kruskal-Wallis, evidenciou-se que prevalecem as estratégias de imposição na gestão de conflitos $(p=0,008)$, sendo as colaborativas mais restritas à periodicidade mensal $(p=0,049)$. Conclusões: os gestores percebem a importância da colaboração na mediação dos conflitos, contudo, no cotidiano, tendem a manter as condutas impositivas, sinalizando para um estilo de liderança pouco transformacional. Descritores: Enfermagem; Gestão em Saúde; Gestor de Saúde; Administração de Serviços de Saúde; Liderança.

\section{RESUMEN}

Objetivos: analizar la percepción y estrategias de administración de conflictos utilizadas por enfermeros en la gestión de personas en servicios de salud portugueses. Métodos: estudio descriptivo, correlacional, realizado en servicios de salud portugueses, con muestra no probabilística intencional, totalizando 95 enfermeros gestores. Se utilizó un cuestionario y escala de gestión de conflictos, siendo analizadas, con auxilio de software, las variables de actividades gerenciales y de gestión de conflictos. Resultados: se identificó que $60 \%$ de los gestores refieren tener que mediar conflictos diariamente, y la mayoría refiere adoptar el diálogo en la conducta. Entretanto, mediante test Kruskal-Wallis, se ha evidenciado que prevalecen las estrategias de imposición en la gestión de conflictos $(p=0,008)$, siendo las colaborativas más restrictas a la periodicidad mensual $(p=0,049)$. Conclusiones: los gestores perciben la importancia de la colaboración en la mediación de los conflictos, sin embargo, en el cotidiano, tienden a mantener las conductas impositivas, señalizando para un estilo de liderazgo poco transformacional.

Descriptores: Enfermería; Gestión en Salud; Gestor de Salud; Administración de Servicios de Salud; Liderazgo. 


\section{INTRODUCTION}

Nursing develops activities that include the provision of care and management activities in organizations. As managers, nurses assume the role of leaders, with leadership being understood as the ability to influence their team, aiming to achieve goals shared by the group and with the central purpose of meeting the health needs of users and their families ${ }^{(1-2)}$. Among the main attributions of the leader, there is the management of conflicts, generally characterized with a certain negative connotation, related to the breaking of the order, caused by error or failure, being the management the ability to manage them ${ }^{(3)}$. These are also the result of differences in ideas, values, cultures or feelings of two or more people ${ }^{(2)}$, can be interpreted as destructive or constructive ${ }^{(4)}$, which will depend on the conduct adopted by nurses when managing them.

Conflicts are inevitable in spaces where there are interactions between people; and, depending on their intensity, the way they are treated, can be beneficial in the work environment. Different studies ${ }^{(1-5)}$ in the area of nursing management have focused on analyzing and/or understanding nurses' ability to handle conflicts, considered a common stressor in the practice of these professionals, which strive to achieve the satisfaction goals of users, institutions and their employees, providing quality service. Because the nurse manager realizes that support can impact stress levels at work and the way in which she deals with conflict ${ }^{(6)}$, leadership style is also decisive in this context ${ }^{(7)}$, as well as the nurses' personality traits, which affect conflict management strategies ${ }^{(8)}$. These aspects can interfere in interpersonal relationships, in teamwork and, in turn, in nursing care.

A study ${ }^{(9)}$ signals that ineffective conflict management is a threat to teamwork. In addition, it highlights the scarcity of knowledge related to the resolution of conflicting situations. In view of this finding, the nurse manager needs to develop skills, with a view to assessing and choosing the best strategy to handle conflicting occasions, recognizing such managerial competence as a priority, in view of the fact that it affects patient safety and the reduction of health damage, through cohesive and effective teamwork.

Another investigation ${ }^{(8)}$ points out that nurses working in management positions should support others in adopting strategies to resolve conflicts in a more assertive way. The results also converge on the importance of incentives to programs that can contribute to the improvement of skills that support the management of conflicting events.

For all these reasons, it is also reinforced as an assumption of this investigation that conflict management is a relevant issue within health care contexts around the world, therefore identifying nurses' conduct towards conflict management and their management strategies are central aspects in the management of health and nursing services.

In this context, this study emerged from the questions: What is the perception of the frequency of conflicts in people management among nurse managers in Portuguese health services? Is this perception associated with the strategies that are used?

\section{OBJECTIVES}

To analyze the perception and conflict management strategies used by nurses in the management of people in Portuguese health services.

\section{METHODS}

\section{Ethical aspects}

The research was approved by the Ethics Committee of each of the institutions (n. 166/17 / RS, n. 93 / CE / JAS and LHU - n. $166 / 17$ / RS of CHSJ - n. 4/17) and followed the ethical precepts of anonymity, right to information and participation in research.

\section{Type of study}

This is a descriptive, exploratory, quantitative, correlational study.

\section{Study scenario and sample}

The research was carried out in three health institutions in the Northern region of Portugal, chosen because they are in the same region and represent a public university hospital; a private hospital; and a local health unit (LHU). In the latter, primary health care and also hospital care are offered, thus including the different types of hospital care available to the Portuguese population.

\section{Study protocol}

The service manager nurses were invited to the study, with the sample calculated in an intentional non-probabilistic way, totaling 95 nurses, which characterized $59 \%$ of the eligible nurses (160 nurses). As inclusion criteria, the following were used: to be a manager appointed for the position that works in the services of interest; and have at least five years of professional experience. Those excluded from services for more than three months due to illness were excluded.

The data collection instruments applied were the Nursing Manager's Job Perception Scale (NMJPS) and the Conflict Management $\mathrm{Scale}^{(2)}$, answered by head nurses responsible for THE service.

The first instrument consists of sociodemographic data, with 14 management activities, and evaluates each activity according to a Likert-type scale, with an interval from 0 to 4 , in which: $0=$ does not perform; 1 = does not take time; 2 = takes up little time; 3 = takes some time; and 4 = takes up most of the time. The total score of the Scale can vary between 0 and 56 points. This instrument obtained, in Cronbach's alpha test, a value of 0.911 .

The Conflict Management Scale, on the other hand, allows analyzing the ways in which conflicts are handled, being organized into: abstention strategies (D1), in which the behavior of the manager turns to avoiding the conflict, assuming a posture of indifference regarding conflicting situations; accommodation strategies (D2), in which the conflict manager uses expectations, thoughts, suggestions from others; enforcement strategies (D3), in which coercion is used as a way to "restrain" a situation and which does not necessarily need to be approved by those involved; and the conciliation strategies (D4), which concern the use of efforts towards an agreement, seeking a suitable measure for both parties. Still, there are collaboration strategies (D5), in which managers seek information and suggestions from the parties from the perspective that the solution is acceptable to all(2).

The information was obtained between February 2017 and July 2018, collected at the health services, by prior appointment and authorization from the heads, in reserved spaces. 


\section{Analysis of results}

The data underwent statistical analysis. Quantitative variables were measured as median, mean and standard deviation, with a $95 \%$ confidence interval. The normality distribution of the variables was assessed using the Kruskal-Wallis test and the Mann-Whitney U test.

The perceptions and attitudes of nurse managers in the face of daily work conflicts were qualitative variables of interest, tested by applying the chi square test, being considered a significance level of $5 \%(p<0.05)$, and expressed as absolute frequencies.

For all tests, the program was supported by the Statistical Package for the Social Sciences (SPSS), version 21.0 for Windows.

\section{RESULTS}

Thirty nurses from the public university hospital (31.6\%), 25 nurses from the private hospital (26.3\%) and 40 from the LHU (42.1\%) were included in the study. Among the 95 participants, there was a predominance of females ( $n=59 ; 62.1 \%$ ), with a general average age of 47.1 years ( \pm 7.8 , minimum of 29 and maximum of 63 years). The average professional practice time was 27.73 years $( \pm 5.1$, minimum of 14 years and maximum of 40 years); and, in management, 12.63 years ( \pm 6.5 , minimum of one full year and maximum of 30 years).
With regard to complementary training, at the specialization level, $89.5 \%(n=85)$ had at least one lato sensu course, of which $62.1 \%(n=59)$ were specific in the area of management.

\section{Activities that permeate people management according to nurse managers}

Initially, managerial activities that pervade people management among nurses were identified, with the findings shown in Table 1.

It became evident that most managerial activities occupy "little" or "some time" for managers. Still, for most of them, there are a percentage of managers who do not perform them.

The instrument made it possible to identify managers' perceptions and behavior in face of conflicts faced in the context of people management. Initially, it was questioned how often the manager perceives to be experiencing the need to manage conflicts in his performance, identifying that $60 \%$ manage them daily, 19\% weekly, 13\% monthly and $7 \%$ annually, confirming themselves if the presence of conflicting situations in the context of the practice of nurse managers. Table 2 seeks to present how managers perceive their conduct in conflict management.

Table 1 - Distribution of time in people management activity according to participants, north region, Portugal, 2017-2018

\begin{tabular}{|c|c|c|c|c|c|}
\hline Activities performed in the management people & $\begin{array}{c}\text { Not } \\
\text { performed } \\
\%\end{array}$ & $\begin{array}{c}\text { It takes up } \\
\text { no time } \\
\%\end{array}$ & $\begin{array}{c}\text { Takes up } \\
\text { little time } \\
\%\end{array}$ & $\begin{array}{c}\text { Takes up } \\
\text { some time } \\
\%\end{array}$ & $\begin{array}{c}\text { It takes up most } \\
\text { of the time } \\
\%\end{array}$ \\
\hline 1. Promote meetings with nurses & 10.5 & 16.8 & 36.8 & 30.5 & 5.3 \\
\hline 2. Assist in the shift change & 14.9 & 9.6 & 27.7 & 34 & 13.8 \\
\hline 3. Assess nurses' performance & - & 6.3 & 50.5 & 33.7 & 9.5 \\
\hline 4. Coordinate the process of integration of employees and assume a role of reference & 4.2 & 11.6 & 42.1 & 37.9 & 4.2 \\
\hline 5. Calculate nurses' needs according to service conditions & 4.2 & 11.6 & 42.1 & 29.5 & 12.6 \\
\hline $\begin{array}{l}\text { 6. Guide nurses according to the intensity and complexity of care, using methodologies that allow } \\
\text { to calculate, in advance, the number of hours of care needed }\end{array}$ & 10.5 & 5.3 & 32.6 & 44.2 & 7.4 \\
\hline 7. Create, maintain and develop cohesion, team spirit and a work environment, managing conflicts & - & 5.3 & 41.1 & 38.9 & 14.5 \\
\hline 8. Distribute nurses according to patients' needs & 7.4 & 9.5 & 38.9 & 36.8 & 7.4 \\
\hline 9. Promote team commitment and motivation (global view) & - & 3.2 & 46.3 & 38.9 & 11.6 \\
\hline 10. Ensure formal communication mechanisms for the team and other employees & - & 10.5 & 47.4 & 35.8 & 6.3 \\
\hline 11. Ensure the planning, organize, coordinate and evaluate the quality of support services & 2.1 & 18.9 & 37.9 & 33.7 & 7.4 \\
\hline 12. Acting as a trainer in the multidisciplinary and intradisciplinary team & 3.2 & 10.5 & 48.4 & 33.7 & 4.2 \\
\hline 13. Promote and evaluate the professional satisfaction of nurses and other employees & 1.1 & 2.1 & 48.4 & 41.1 & 7.4 \\
\hline 14. Create and maintain the conditions for cooperative work among team members & 8.4 & 14.7 & 38.9 & 26.3 & 11.6 \\
\hline
\end{tabular}

Table 2 - Response of nurse managers on conflict management in Portuguese hospitals, Portugal, 2017-2018

\begin{tabular}{|c|c|c|c|}
\hline $\begin{array}{l}\text { Questions } \\
\text { ( } N=95 \text { participants) }\end{array}$ & $\begin{array}{c}\text { Never/Rarely* } \\
(\%)\end{array}$ & $\begin{array}{l}\text { Frequently } \\
\text { (\%) }\end{array}$ & $\begin{array}{c}\text { Always } \\
\text { (\%) }\end{array}$ \\
\hline 1. Try to avoid putting yourself in an unpleasant situation and disagreements & 21.2 & 42.6 & 36.2 \\
\hline 2. Avoid open discussions of differences between parties & 43 & 25.8 & 31.2 \\
\hline 3. Try to keep the differences you perceive and are not yet explicit, to avoid resentment & 22.1 & 37.9 & 40 \\
\hline 4. Attempts to satisfy the expectations of the parties involved in the conflict & 7.5 & 42 & 50.5 \\
\hline 5. Seeks to conform to the wishes of those involved & 54.7 & 27.4 & 17.9 \\
\hline 6. Agrees with the solution proposed by the parties & 26.3 & 66.3 & 7.4 \\
\hline 7. Discuss your opinion with the unit's professionals to show your view of the situation & 8.5 & 36.8 & 54.7 \\
\hline
\end{tabular}




\section{Never/Rarely*}

(\%)

21.1

25.5

6.3

31.9

37.9

5.3

$-$

\begin{tabular}{cc}
$\begin{array}{c}\text { Frequently } \\
\text { (\%) }\end{array}$ & $\begin{array}{c}\text { Always } \\
\text { (\%) }\end{array}$ \\
\hline 58.9 & 20 \\
36.2 & 38.3 \\
47.4 & 46.3 \\
39.4 & 28.7 \\
54.7 & 7.4 \\
41 & 53.7 \\
36.8 & 63.2 \\
34.7 & 65.3 \\
\hline
\end{tabular}

Note: *To better present the results, the options "rarely" and "never" were combined, and accumulated percentages were used, that is, abstentions were excluded, which were at most two, in five questions.

Analysis of the results revealed varied use of conflict management, including abstentions, accommodation, enforcement strategy, conciliation strategy and collaboration strategy.

\section{The relationship between conflict perception, people management and management strategies}

Statistical analyzes made it possible to identify how the perception of conflict frequency is associated with people management. Still, it was shown that the perception of conflict interferes with the strategies used by nurse managers, which are presented in Figures 1 and 2, for which the findings required asymptotic significance and a significance level of 0.05 ( $p$ value).

\section{Independent-Samples Kruskal-Wallis Test}

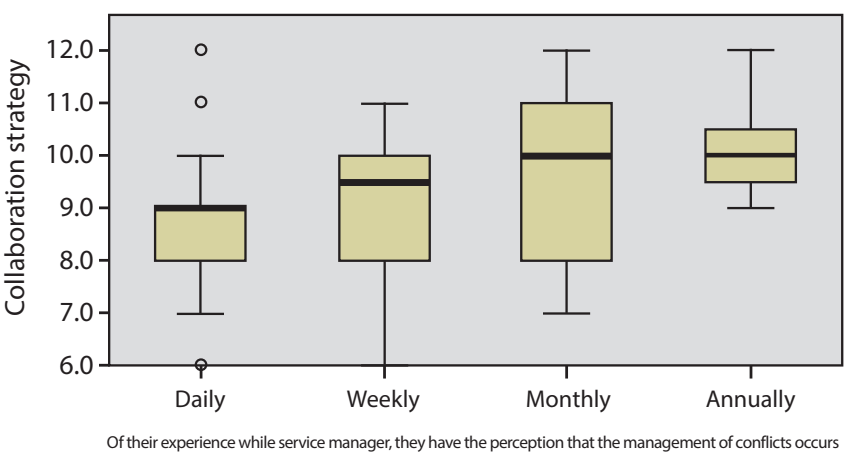

Figure 1 - Analysis of periodic imposition strategies

Independent-Samples Kruskal-Wallis Test

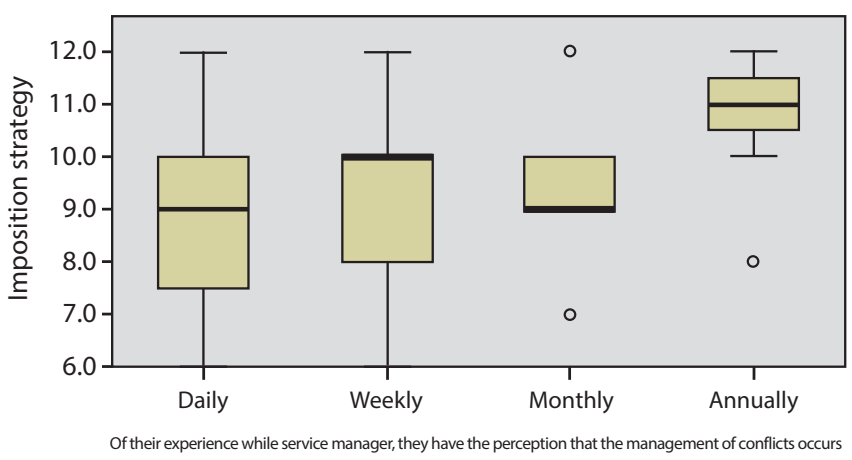

Figure 2 - Analysis of collaboration strategies in relation to the manager's perception that conflict management occurs
It became evident that, on average, managers use enforcement strategies more commonly, that is, daily $(p=0.008)$, with collaboration strategies occurring more frequently, monthly. A smaller group of managers perceives that conflicts occur annually and has higher values of conflict perception.

There are significant differences in conflict management strategies and some activities of managers, and it should be noted that sometimes, for the same activity, they develop different strategies, as shown in the chart below.

Chart 1 - Significant differences between conflict activities and strategies, Portugal, 2017-2018

\begin{tabular}{|l|c|c|}
\hline Activity & Conflict strategy & $\mathbf{P}$ \\
\hline \multirow{2}{*}{ Assist in the shift change } & Accommodation & 0.002 \\
\cline { 2 - 3 } & Collaboration & 0.004 \\
\hline $\begin{array}{l}\text { Coordinate the process of integration of } \\
\text { employees and assume a role of reference }\end{array}$ & Conciliation & 0.020 \\
\hline $\begin{array}{l}\text { Calculate nurses' needs according to service } \\
\text { conditions }\end{array}$ & Accommodation & 0.041 \\
\hline $\begin{array}{l}\text { Guide nurses according to the intensity and } \\
\text { complexity of care, using methodologies that } \\
\text { allow calculating, in advance, the number of } \\
\text { hours of care needed. }\end{array}$ & Accommodation & 0.023 \\
\cline { 2 - 3 } $\begin{array}{l}\text { Create, maintain and develop cohesion, } \\
\text { team spirit and a work environment, } \\
\text { managing conflicts }\end{array}$ & Accommodation & 0.044 \\
\hline $\begin{array}{l}\text { Distribute nurses according to patients' } \\
\text { needs }\end{array}$ & Accommodation & 0.041 \\
\cline { 2 - 3 } & Collaboration & 0.000 \\
\hline \multirow{2}{*}{$\begin{array}{l}\text { Ensure the planning, organize, coordinate and } \\
\text { evaluate the quality of support services }\end{array}$} & Accommodation & 0.011 \\
\cline { 2 - 3 } & Conciliation & 0.029 \\
\hline $\begin{array}{l}\text { Create and maintain the conditions for } \\
\text { cooperative work among team members }\end{array}$ & Accommodation & 0.001 \\
\cline { 2 - 3 } & Collaboration & 0.016 \\
\hline
\end{tabular}

When all activities and the Scale are analyzed in full, significant differences in activities occur "Distribute nurses according to patients' needs" ( $p=0.011)$ and "Ensure planning, organize, coordinate and evaluate the quality of support services" $(p=0.012)$.

\section{DISCUSSION}

Among the participating managers, there was a predominance of nurses with experience in the services, but with limits regarding 
training in management. A study ${ }^{(10)}$ in the hospital area brings an association between the level of education, position and professional career of nurses; and between the conflict management courses and the conflict management strategies that nurses adopt. In this direction, it is signaled that the experience added to professional development to manage conflicts can facilitate the management of people, as well as interpersonal relationships, the decision-making and negotiation process, constructively strengthening the organizational climate.

It is considered that conflict management requires experiences, as well as knowledge that must be sought and improved, especially through permanent education strategies in services, which require investments by professionals and institutional support, in an exchange process that has benefits for organizations and people.

It became evident that most managerial activities occupy "little" or "some time" of managers, all of whom perform performance evaluation, seek to create, maintain and develop cohesion, team spirit and a work environment, managing conflicts. Still, in proportions of time distribution, they are involved in promoting the commitment and motivation of the working group, in the search to ensure formal communication mechanisms for the team and other collaborators. However, most of the activities presented a percentage of managers who do not perform them, perhaps due to the distribution of tasks among other managers and / or colleagues, or due to technical regulations of the institution. It is also worth reflecting that some managers really avoid conflict management, avoid it. Dealing with people demands a lot from the professional, which can trigger an exhausting process, and not everyone is prepared for it.

In health organizations, especially hospitals, management involves greater complexity, as it aims at satisfying both internal and external customers, always seeking to meet quality standards. In Portugal, nowadays there is a different reality from the 1980s, guided by changes especially induced by information technologies — integrating automatic data analysis, image — and by artificial intelligence, which brings changes in management in the provision of care, with implications for work processes, particularly in organizations and in the production of health responses. Such changes also occurred in the organizational model of Portuguese hospitals, which introduced new management dynamics, with an emphasis on clinical governance, ensuring that citizens participate in decision-making processes, through satisfaction assessment surveys and the presentation of suggestions ${ }^{(11)}$.

In the wake of the changes and driven by increased activity costs, wasted resources and low production of care services, the government of Portugal opted, in the 1990s, for the European model of New Public Management. Based on this, management practices were rethought, reinforcing the power and responsibility of managers, with greater concern for the effectiveness, efficiency and effectiveness of services, a situation that implied the need for more training for nurse managers ${ }^{(12)}$.

It was identified that $60 \%$ of managers mediate conflicts on a daily basis, with the majority reporting avoiding making explicit the differences, with a view to minimizing resentment, seeking to satisfy the expectations of the parties involved, discuss your opinion with the professionals to show your view on the situation, reflect on the issue under discussion to find an acceptable collective solution, exchange accurate information about the case to solve a problem together. Collaborative strategies focus on attempts to understand the case, tend to value accurate information about the situation, directing the solution of the conflict with the collaboration of the parties involved, avoiding resentment or dissatisfaction. This can be differential for the problem to stop occurring or to occur less frequently. However, nurse managers also seek to support their opinion regarding the solution to the problem and usually do not give up on it.

In this sense, the importance of the leader's profile is observed, because most of the times, the characteristics of this prevail in the management of emerging conflicts. The relevance of investments in the training of leading nurses during the undergraduate course is also highlighted, with transformational characteristics, open to new behaviors and the learning that the team can promote. This is reinforced in the management strategies identified in the research.

When asked about the perception of management strategies for each activity, all types of behavior were mentioned, from abstentions, accommodation, imposition, conciliation and collaboration. However, the analysis revealed that imposition conduct in the daily context is more common, the finding differs from recent publications on the subject in other studies ${ }^{(1,10,13-14)}$.

$\mathrm{Na}$ investigation ${ }^{(10)}$ on the subject identified that accommodation strategies are inversely related to the frequency of interpersonal conflict, these tend not to solve the problem. Instead, they postpone resolution and may increase the damage done. The domination/imposition strategy, positively related to the increase in interpersonal conflicts, may occur because domination is a type of competition strategy, which is associated with an increase in the frequency of interpersonal conflicts. In these strategies, an aspect that potentially weakens the professional category of Nursing is observed, as it causes ruptures that do not allow advances in collaborative and empathic work, capable of uniting subjects in common interests.

Inadequate solutions have a negative impact on team relationships, lead to discomfort, anxiety, stress, poor communication, which influences the effectiveness of services and directly implies the quality and safety of care ${ }^{(1,5,15)}$. In addition, the proper negotiation and resolution of conflicts is the key to promote the retention of professionals, since the high turnover, the shortage of workers and absenteeism are challenges for the nurse manager ${ }^{(12,14)}$ and can also be significant barriers to exercising leadership.

As the conflict has direct implications for service users, positive resolution is essential to promote safe and effective provision of care, while stimulating therapeutic relationships between colleagues and managers ${ }^{(7)}$, preserving the organizational climate and satisfaction in the work environment.

Researchers point out some strategies that can contribute to conflict management, including the practice of dialogical leadership $^{(1)}$ and/or transformational ${ }^{(16-17)}$. In these models, communication is the essential tool in managing problems. Transformational leaders exercise effective communication that encourages trust, engagement and, consequently, greater satisfaction of team members ${ }^{(18-19)}$. Collaborating with the findings, a study ${ }^{(20)}$ identified the adoption of dialogue as a strategy for coping with stressful 
situations, adopted by leading nurses in the workplace. It also mentions that conflict management is characterized as a competence of nurses, based on impartial attitudes and attentive listening, configuring one of the pillars of support for leadership.

Communication is considered an efficient tool, easy to use and access, and capable of better handling conflicts, based on a clear and reciprocal understanding, effective negotiations, which drives processes and changes, enhances the quality of teamwork and consequently, the quality of care $(1,10,15-16)$.

It is worth noting the sum of managers who say that they do not carry out, do not occupy time or take up little time, holding meetings (64.1\%), watching the shift change (52.2\%) or seeking to ensure formal communication mechanisms for the team and other employees (57.9\%). These moments constitute central spaces for the continuity of care, which indicates activities of the work process that require greater appreciation on the part of managers, staff and institutions.

Another caveat lies in the perception that collaborative views are related to constructive processes, which offer an opportunity for an educational intervention, so that they can contribute to the analysis of problems and learn how to manage conflicts with effective collaborative processes ${ }^{(4)}$. However, in this research it was identified that $62.1 \%$ of the managers do not work or act little as trainers in the multidisciplinary and intradisciplinary team. This finding may be related to institutional culture, which, at times, does not excel in the construction of spaces for communication and collective learning of employees.

It is important to consider the causes of conflicts, effective management and the relevance of positive approaches, with a view to resolving them. In this context, leadership stands out as a professional competence of nurses, which seeks to stimulate the dynamics and the process of effective and horizontal communication, aiming at the shared solution of problems and the acceptance of changes ${ }^{(1,7)}$. Given the above, it is worth mentioning the relevance of institutional support to nurse managers, in terms of conflict management and the leadership process. The itinerary of these managerial competencies cannot be seen as a solitary path, which is exclusively the responsibility of the manager, but must be understood as everyone's responsibility, from the high organizational level to the operational base, being embedded in the organizational culture.

Researchers ${ }^{(5,7,10,16,21-22)}$ suggest strategies to better manage conflicts, such as: developing emotional intelligence, training programs in conflict management, developing leadership potential; permanent health education actions, welcoming new team members, seeking their support and integration with others, to encourage mutual respect for roles between all team members and establish positive working relationships. These strategies can also be decisive to avoid the appearance of conflicting spaces and enhance the collective's capacity to face problems.

Another aspect that should be mentioned is the importance of the approach to conflict management in the training of nurses as a cross-cutting theme, which should be explored throughout the teaching and learning process, in order to prepare students to handle conflicting situations ${ }^{(1,22)}$. In addition, it is worth remembering that the skills of greater sustainability for conflict management include leadership, communication and teamwork, which must be acquired during the training process of nursing students, in order to strengthen their performance while future professionals $^{(23)}$.

The implementation of institutional programs with a focus on conflict management can contribute to the constant learning of nurse managers and lead their decisions in a more assertive and qualified way, effectively assisting both the management of the team and the nursing care.

Still, investigators ${ }^{(10)}$ identified important findings with regard to previous experience in other services, which can contribute to improving leaders' ability to lead conflicts, with the hiring of managers with this experience a possibility in sectors with a high incidence of problems.

\section{Study limitations}

The study had some limitations, such as not including professionals from all regions of the country, which points to the need for research in other services, as well as the lack of information on why some typical activities of managers were registered as not performed by participating nurses, and the qualitative approach could complement these and other findings. However, overall, the results highlight important issues in conflict management in health service contexts, which are likely to be repeated in other regions of Portugal and in other countries.

\section{Contributions to the area of Nursing and Health}

Contributions to nursing and the health area lie, especially, in the findings that allow a better understanding of nurses' competences in conflict management, of challenges in the praxis of leaders, which interfere in the direction of teams and, consequently, in the quality of services and care management. The findings bring suggestions that can assist in investments in professionals and institutions for the implementation of conflict management strategies. The text makes reservations about the approach of the theme in the process of formation and permanent education.

\section{FINAL CONSIDERATIONS}

The study analyzed the perception of conflict management strategies used by nurses in people management in Portuguese health services, revealing that they perceive and value dialogical and collaborative strategies in conflict management. However, enforcement strategies predominate on a daily basis, with the most occasional collaboration strategies. Thus, to better manage conflicts, investments are needed to foster transformational leadership among managers, using communication and behaviors that facilitate coping and reducing conflicts in health services more frequently.

It is worth highlighting the diversity and complexity of the duties and responsibilities of nurse managers, which requires a sum of efforts in the field of training from undergraduate to postgraduate, reaching the service, permanently, to provide conditions for these professionals, which will have an impact on the performance of the other professionals on the teams and on the quality of services provided in health institutions. 


\section{REFERENCES}

1. Amestoy SC, Backes VMS, Thofehrn MB, Martini JG, Meirelles BHS, Trindade LL. Gerenciamento de conflitos: desafios vivenciados pelos enfermeiros-líderes no ambiente hospitalar. Rev Gaucha Enferm. 2014;35(2):79-85. doi: 10.1590/1983-1447.2014.02.40155

2. Costa JO, Souza MNA, Feitosa ANA. Gestão de conflitos: estratégias adotadas em unidade básica de saúde. Rev Adm Saúde[Internet]. 2013[cited 2019 Apr 15];15(61):135-40. Available from: https://www.researchgate.net/ publication/286084430_Gestao_de_conflitos_estrategias_adotadas_em_unidade_basica_de_saude

3. Kurgant P. Gerenciamento em enfermagem. Rio de Janeiro: Guanabara Koogan; 2012.

4. Kim WS, Nicotera AM, McNulty J. Nurses' perceptions of conflict as constructive or destructive. J Adv Nurs. 2015;71(9):2073-83. doi: 10.1111/ jan.12672

5. Başoğul C, Özgür G. Role of emotional intelligence in conflict management strategies of nurses. Asian Nurs Res. 2016;10(3):228-33. doi: 10.1016/j.anr.2016.07.002

6. Johansen ML, Cadmus E. Conflict management style, supportive work environment and the experience of work stress in emergency nurses. J Nurs Manag. 2016;24(2):211-8. doi: 10.1111/jonm.12302

7. McKibben L. Conflict management: importance and implications. Br J Nurs. 2017;26(2):100-3. doi: 10.12968/bjon.2017.26.2.100

8. Erdenk N; Altuntas S. Do personality traits of nurses have an effect on conflict management strategies? J Nurs Manag. 2017;25(5):366-374. doi: $10.1111 /$ jonm.12474

9. Grubaugh ML, Flynn L. Relationships among nurse manager leadership skills, conflict management, and unit teamwork. JONA: J Nurs Adm. 2018;48(7/8):383-8

10. Chang TF, Chen CK, Chen MJ. A study of interpersonal conflict among operating room nurses. J Nurs Res. 2017;25(6):400-10. doi: 10.1097/ JNR.0000000000000187

11. Teles J. Particularidades da gestão de enfermagem em instituições psiquiátricas. Rev Port Enferm Saúde Mental. 2017;(spe5):6-7. doi: $10.19131 /$ rpesm.0159

12. Nunes AM, Matos AA. Experiências de gestão hospitalar realizadas em Portugal: uma perspectiva comparada. Gestão Prod. 201;8(2):284. doi: 10.18673/gs.v8i2.24601

13. Al-Hamdan Z, Nussera H, Masa'deh R. Conflict management style of Jordanian nurse managers and its relationship to staff nurses' intent to stay. J Nurs Manag. 2016;24(2):E137-45. doi: 10.1111/ jonm.12314

14. Ahanchian MR, Emami Zeydi A, MR Armat . Conflict management styles among Iranian critical care nursing staff: a cross-sectional study. Dimens Crit Care Nurs. 2015;34(3):140-5. doi: 10.1097/DCC.0000000000000106

15. Camelo SHH, Soares MI, Chaves LDP, Rocha FLR, Silva VLS. Enfermeiros gerentes de um hospital de ensino: formação profissional, responsabilidades e desafios. Rev Enferm UERJ. 2016;24(3):1-6. doi: 10.12957/reuerj.2016.11637

16. Amestoy SC, Trindade LL, Silva GTR, Santos BP, Reis VRSS, Ferreira VB. Liderança na enfermagem: do ensino ao exercício no ambiente hospitalar. Esc Anna Nery. 2017;21(4):e20160276. doi: 10.1590/2177-9465-ean-2016-0276

17. Ferreira VB, Amestoy SC, Silva GT, Felzemburgh RD, Santana N, Trindade LL, et al. Transformational leadership in nurses' practice in a university hospital. Acta Paul Enferm. 2018;31(6):644-50. doi: 10.1590/1982-0194201800088

18. Yang YF. Examining competing models of transformational leadership, leadership trust, change commitment, and job satisfaction. Psychological Reports; 2016.

19. Abelha DM, Carneiro PCC, Cavazotte FSN. Liderança transformacional e satisfação no trabalho: avaliando a influência de fatores do contexto organizacional e características individuais. Rev Bras Gest Neg. 2018;20(4):516-32. doi: 10.7819/rbgn.v0i0.3949

20. Reis CD, Amestoy SC, Silva GT, Santos SD, Varanda PA, Santos IA, et al. Situações estressoras e estratégias de enfrentamento adotadas por enfermeiras líderes. Acta Paul Enferm. 2020;eAPE20190099. doi: 10.37689/ acta-ape/2020AO0099

21. Chan JC, Sit EN, Lau WM. Conflict management styles, emotional intelligence and implicit theories of personality of nursing students: a cross-sectional study. Nurse Educ Today. 2014;34(6):934-9. doi: 10.1016/j.nedt.2013.10.012

22. Amestoy SC, Oliveira AFL, Thofehrn MB. Contributions of Paulo Freire to understanding the dialogic leadership exercise of nurses in the hospital setting. Rev Gaúcha Enferm. 2017;38(1):e64764. doi: 10.1590/1983-1447.2017.01.64764

23. Beserra EP, Gubert FM, Martins MC, Vasconcelos VM, Figueiredo GA, Silva LA, Lima MA. Conflict management in nurse training. Rev Enferm UFPE. 2018;12(10):2891-6. doi: 10.5205/1981-8963-v12i10a236080p2891-2896-2018 